Roberts's lamp was described as being "surrounded by a double tube of wire gauze, and also by a glass chimney, and is so constructed that a current of carbonic acid air or nitrogen passes continually between the external atmosphere and the flame of the lamp. . . . To comprehend the nature of this invention fully, it is necessary to see the lamp, and compare it with the lamp hitherto used, over which it has certainly a manifest advantage. It is very simple in its construction, and as a committee of the House of Commons are now examining matters of this nature, it will no doubt meet with the encouragement it deserves".

\section{London's Water Supply}

Commenting on a proposal to supply London with water pumped from wells by steam engines, the Athenceum of June 27, 1835, after reviewing the project, said : "The annually decreasing quantity of water in the London bason is also to be remarked. The fall in the level of the wells is, according to credible evidence, about one foot per annum; and there has been a decrease of full twenty feet within the last twenty years. Though this gradual fall is certainly not an object of immediate apprehension, as to the total failure of the supply, yet the infinitely more rapid ratio of decrease which would ensue, if the whole metropolitan supply were taken from the same source, must be obvious.

"For these reasons we have come to the conclusion that though London is supplied with a considerable abundance of the most salubrious well-water for general purposes of domestic use-yet, that to draw upon the bason for the whole of the supplies by means of steam power is, if not objectionable for other reasons, impracticable by reason of the expense of the many divided establishments which must necessarily be required for the production of $20,000,000$ galls. per day, which is the generally estimated quantity used in the metropolis".

\section{The Hot Blast at the Butterley Iron Works}

For some years after the introduction by Neilson of the hot-blast, there was considerable controversy over its merits. One of its advocates was Joseph Glynn, F.R.S. (1799-1863), who was engineer to the Butterley Iron Works, near Derby. In a letter of his published in the Mechanics' Magazine of June 27, 1835, he said : "The Butterley Company employ in their mines, coal-fields, blast furnaces, rolling mills, forges, boring mills and steam engine factory, 35 steam engines of all sizes, from 80 inches of diameter of cylinder, and have six blast furnaces, of which four are now at work. The whole of these furnaces are blown with heated air, and the coal, which is admirably adapted for the purpose, needs no cokery, being very carbonaceous. The mountain limestone which lies but three miles from the furnace, is used. as flux for the ore, which is clay iron-stone. These materials produce a very fine grained cast-iron, remarkably soft and fluid, and at the same time they are equally well adapted to make 'forge pigs' from which are manufactured bars, hoops and boiler plates, of best quality and steam engines. ... M. Dufresnoy, M. Perdonnet, and several other Frenchmen of scientific reputation, have visited the Butterley Company's works, with which they have been highly pleased, and have been willing to communicate the valuable information they possess, in return for such as was afforded them here".

\section{Societies and Academies}

\section{DUBLIN}

Royal Irish Academy, May 27. Winifred E. Frost : Larval stages of the Euphausiids Nematoscelis megalops and Stylocheiron longicorne taken off the south-west coast of Ireland. The euphausiids form an important part of the fauna of the inshore and deep waters off the south and west coast of Ireland. The present paper deals with the life-histories of two of these animals, the development of which has not previously been described. Sufficient larval stages have been found to give a good idea of the life-history of the organisms and the descriptions make it possible to identify the larvæ in the plankton. Some notes are given on the reproductive cycles of the two euphausiids.

\section{ParIS}

Academy of Sciences, May 6 (C.R., 200, 1553-1640). LuCIEN CAYEUX: The constitution of the Senonian phosphates of Syria. Alexandre GuILLIERMOND : A new fungus, a parasite of the capsules of the cotton plant. Eremothecium Ashbyii and its possible relations with Spermophthora Gossypii and the Ascomycetes. Armand de Gramont and Daniel Beretzki : The stabilisation of a frequency of beat (quartz oscillators) by compensation of the temperature coefficients. The method is based on the use of two piezoelectric quartz crystals and different frequencies and determined temperature coefficients. The arrangement is more stable than that utilising a single quartz with low temperature coefficient, and its constancy over a range of $50^{\circ} \mathrm{C}$. is equal to a single quartz kept within $0 \cdot 1^{\circ} \mathrm{C}$. Henri Devaux : The adsorption of ovalbumen at the free surface of its solutions when the concentration of these varies from $10^{-2}$ to $10^{-8}$. Georges TzITzÉICA : Some affine properties. Ivan BraittzefF : The singularities of special types of $a$ function given by its development in a Dirichlet series. Michel Krawtchouk: Some inequalities in the problem of moments. NATAN AronszaJn: The singularities of the Riemann surfaces of inverse functions of integral functions. HENRr MrNEUR : Mechanical systems admitting $n$ uniform first integrals and the extension to these systems of Sommerfeld's method of quantification. MrRoslav NÉNADovitch : Contribution to the study in a plane current of rigid biplane cells. RAOUL GoUDEY : Measurements of the intensity of gravity, made in 1933, with the Holweck-Lejay gravimeter No. 2. GEorges DÉCHÈnE : The discharge rays emitted by a brush discharge. Contrary to the views of Dauvillier, the author's experiments confirm the existence of discharge rays. Mule. M. Quintin : Study of the electromotive force of cadmium chloride batteries. François Croze : The general formulæ of the refraction of a light bundle. Jean PaUl Mathieu and JACQUES PERRICHeT : The rotatory dispersion of the $\alpha$-halogen derivatives of camphor. André Claude : Incandescent lamps containing krypton and xenon. A summary of results obtained with more than 10,000 bulbs. On account of the lower heat conductivity of krypton and xenon compared with that of argon the bulbs can be made smaller, a litre of gas filling $20-30$ bulbs. The temperature of the filament can be raised, owing to the slower diffusion of the tungsten vapour. Jean Perreu: The tono. metry of saline solutions. PaUl Abadie and Georges ChAMpetien : The determination of some dielectric 
properties of heavy water. PAUL GOLDFINGER, Wladimir LasarefF and Morice Letort : Thermochemical considerations on the carbonyl group. Pierre Spacu: A method for the quantitative separation of iron and cobalt. The ferric iron is precipitated by pyridine and the cobalt in the filtrate precipitated as the ammine $\mathrm{CoPy}_{4}(\mathrm{SCN})_{2}$. MARCEL PATRY : The properties of allotelluric acid. MARCeI Godchot, Max Mousseron and Roger Richaud : The $\Delta_{2}$ and $\Delta_{3}$ I-methylcyclopentenes and their derivatives. V. M. MIтсноviтcн: The action of $o$-chlorcyclopentanone on the organomagnesium halides. Frrmin Govaent : The use of liquid hydrogen chloride in the preparation of the dichlorarsines. Jean Laval : The diffraction of X-rays by the silver atom (factor of structure). HENRI LONGCHAMBON : The chemical formula and constitution of Ampandrandava sepiolite. JEAN ECK and JeAN Menabrea: The arrangement of the faces of the trihedra obtained by the corrosion of a plate of quartz. JosEPH Blayac, Rodolphe Böhm and Gaston Delúpine : A new Goniatite fauna in the Visean of MontagneNoire. H. Besairie, P. Gruyelle, A. Lenoble and A. SAvornis: The geological and magnetic study of the cliff of Mandraka (Madagascar). V. Frolow: The general characters of the changes of level or of flow. Albert MaIge: New observations on the evolution of the amylogen plasts in the reserve starch cells. Wladyslaw antoni Becker and FrançoIs XAVIER SKUPIENSKI : Vital protoplasmatic observations on Basidiobolus ranarum. ROBERT BONNET and RAYMOND JACQUOT: The variation of the velocity of growth and of respiration in Sterigmatocystis nigra and of the crude energy yield, as a function of the age of the cultures and the source of nitrogen. Caesar R. Scholz: The constitution of corynanthine. Renḱ Soukges : The embryogeny of the Enotheraceæ. The principal terms of the development of the embryo in Ludwigia palustris. RoBERT WEILL : The structure, origin and cytological interpretation of the colloblasts of Lampetia pancerina (Ctenophores). Raoul Husson: The rôle of the laryngeal apparatus in the formation of the timbre of spoken and sung vowels and the genesis of the changes of compass and registers of the voice. MmE. V'́RA DANTCHAKOFF : Endocrinian proliferations at the expense of the germinative epithelium. RENÉ AUDUBERT and Robert LÉvy: The emission of radiation by nerve stimulation. MICHeL FAgUeT : The photometric diagnosis of the Eberth bacillus, of para $A$ and of the coli bacillus. The photometric method of measuring the rate of increase described in a previous note has been applied to twelve strains of coli, eleven strains of the Eberth bacillus and six of para $A$. Each gives its characteristic curve and the photometric diagnosis agrees with the bacteriological diagnosis. GASTON RAMON and EDOUARD LEMÉTAYER : The reinforcement of the immunising action of toxins and antitoxins. The method is based on coating the toxin or anatoxin with lanoline.

\section{Copenhagen}

Royal Danish Academy of Sciences and Letters, February 1. G. Hevesy : Artificial radioactivity of scandium. When scandium is bombarded with neutrons, the product is partly a radioactive isotope of potassium, and partly a radioactive isotope of scan. dium, the former emitting hard, the latter soft $\beta$-rays.

March 1. L. Kolderup Rosenvinge: Some Danish Phæophyceæ. The development of the two species of Stictyosiphon occurring in Danish waters ( $S$. tortilis and $S$. soriferus) has been examined, the germination of the zoospores from the plurilocular sporangia having been observed, in both cases apparently without fusion. In both species a filiform, branched, creeping protonema was produced on which an erect shoot appeared, bearing plurilocular sporangia, just as the mother plant. An alternation of generations therefore does not take place. The morphology of the Danish members of the family Elachistaceæ was discussed.

\section{Geneva}

Society of Physics and Natural History, May 2. FerNAND Chodat: Tyrosinase and glutathione. The experiments carried out prove that glutathione completely inhibits catalyses determined by tyrosinase on tyrosine, $p$-oxyphenylethylamine and the system $p$-cresol-glycocol. The inhibiting rôle of glutathione in melanogenesis in vivo is considered. FERNAND Chodat and André Murimanoff: The ageing of yeasts. Endomyces anomalus is studied from the point of view of its respiration. The ageing consists in leaving fresh yeasts, in buffer solutions of phosphate, with or without sugar at different temperatures. The respiratory power is measured with Warburg's apparatus under these different conditions. G. Trercy : (I) Remarks on the differential equation of the second order met with in cases of polytropic equilibrium of gaseous spheres. The paper discusses the examination of an energy hypothesis utilised by Białobrzeski and by Eddington. (2) The general differential of the second order characterising the thermodynamic equilibrium of gaseous spheres. This equation is complicated; it is always simplified when the case of polytropic equilibrium is considered.

\section{LENINGRAD}

Academy of Sciences (C.R., 1, No. 9, 1935). D. Perepelkin : Parallel varieties in a Euclidian (or Riemannian) space. L. SchIEFNer: The $m$-th power of a matrix. G. KrutKov and V. Dmitriev : Contribution to the theory of Brownian movement. Small fluctuations of a system with $n$ grades of freedom. D. Volkov: An exact solution of the Dirac equation for a flat wave of definite frequency. E. ANDREJEV : Influence of a metallic surface on the kinetics of oxidation of ethane. K. LJaLIKov, I. Protas and G. Farrman : Displacement of the isoelectric point of gelatine. V. Ipatjev and V. Tronev: Mechanism of displacement of noble metals in solutions of their salts by hydrogen under pressure. (1) Displacement of palladium in solutions of palladium chloride. (2) Displacement of metals in the solutions of $\mathrm{H}_{2} \mathrm{PtCl}_{6}, \mathrm{H}_{2} \mathrm{IrCl}_{6}, \mathrm{Na}_{3} \mathrm{IrCl}_{6}$ and $\mathrm{Na}_{3} \mathrm{RhCl}_{6}$. O. IstominA and E. OstrovSKIJ : Effect of super-sonic vibrations on potato growth. K. SukHorukov and T. EPEL-BogoSLOVSKAJA : Action of bios on processes of putrefaction. V. Sharonov: Daylight illumination under different conditions. A. Labuncov : Age of uraninite and monazite from the pegmatite veins of northern Karelia. I. Almmarin : Chemical constitution of tshevkinit. DoNтcho KostofF : Studies on polyploid plants. (10) The so-called 'constancy' of the amphidiploid plants. G. Meller and A. Prokofjeva : Structure of the chromonema of the inert region of the $\boldsymbol{X}$-chromosome of Drosophila. V. KatunskiJ : Growth-promoting substance as a factor in the formation of the plant organism. V. CivinskiJ : 
Critical period of the cotton plant. L. PoLEzHAJEv : Restoration of the regenerative power in tailless amphibians (2).

\section{WashingTON, D.C.}

National Academy of Sciences (Proc., 21, 143-180, March 15, 1935). JAN SchILT: Preliminary note concerning a new theory of the motions of the stars. The parallaxes of stars of spectral type $A$ are used to give rectangular equatorial velocity components, and an expression is derived from which other parallaxes have been derived satisfactorily. The formula incorporates the hypothesis of an expanding stellar system. HARRIET B. CREIGHTON and BARBARA MCCuINTOCK: The correlation of cytological and genetical crossing-over in Zea mays : a corroboration. Chromosome 9 in maize is characterised by the $1: 2$ ratio in length of its two 'arms'; in some strains the shorter arm carries a large knob, whereas in others it is small or absent. This knob has been used as a cytological 'marker'. Frark H. Clark: Two hereditary types of hydrocephalus in the house mouse (Mus musculus). The character is a simple recessive. Since mice with water-on-the-brain are sterile or transit only a low grade of this affection, heterozygous animals were used. When such animals of two strains, one from Michigan and the other from Berlin, were mated, the offspring contained no hydrocephalics, indicating that two different genes are involved in the two strains. Torsten TeoresL : Studies on the 'diffusion effect' upon ionic distribution. (1) Some theoretical considerations. Study of an aqueous system of strong electrolytes where steady diffusion across a boundary permeable to ions takes place. The theory predicts a distribution of ions similar to that for non-diffusible ions indicated by the Gibbs-Donnan equilibrium, which appears as a limiting case of the general theory discussed. Great concentration differences such as occur in biological systems are theoretically possible. H. S. VANDIVER : On the foundations of a constructive theory of discrete commutative algebra (2). J. LEvINE : Conformal-affine connexions. OsWALD VEBLEN : Formalism for conformal geometry. H. BATEMAN and S. O. RICE : Some expansions associated with Bessel functions. RoBert W. WILson : Simimys, a new name to replace Eumysops, Wilson, preoccupied : a correction.

\section{Forthcoming Events}

[Meetings marked with an asterisk are open to the public.]

\section{Sunday, June 23}

British Musedm (Natural History), at 3 and 4.30 . MIss M. Smith: "Reptiles and Fossil Reptiles"."

Monday, June 24

Royal Geographical Socrety, at 3.-Annual General Meeting.

British Waterworks Assoclation, June 25-29. Annual General Meeting and Conference to be held at Cambridge.

South-Eastern Union of Scientific Soctetres, June 26-29. Annual Congress to be held at Bournemouth. Prof. A. C. Seward: "The Herbarium of the Rocks" (Presidential Address).

\section{Official Publications Received}

\section{Great Britain aND IreLaNd}

The Scientific Journal of the Royal College of Science. Vol. 5 ; Containing Papers read during the Session 1934-1935 before the Imperial College Chemical Society, the Royal College of Science Natural History Society, the Royal College of Science Mathematical
and Physical Society. Pp. 138. (London: Edward Arnold and Co.)

and 6 . Physical.

Report of the National Baby Week Council 1934, presented and adopted at the Eighteenth Annual Meeting of the National Baby Week Council held in London on the 27th March 1935. Pp. 24 (London: National Baby Week Council.

Annual Report of the Zoological Society of Scotland for the Year ending 31st March 1935. Pp. $63+6$ plates. (Edinburgh : Zoological Society of Scotland.)

The Scientiflc Proceedings of the Royal Dublin Society. Vol. 21 (N.S.), No. 23: On the Characteristics of Bacterium violaceum (Schröter) and some Allied Species of Violet Bacteria. By George Cruess-Callaghan and M. J. Gorman. Pp. 213-221 + 1 plate. (Dublin Hodges, Figgis and Co.; London: Williams and Norgate, Ltd., 1935.) 18 . The Men of the Trees. Tenth Year's Report and Review of the Tree Year 1934. Pp. $39+4$ plates. (London: Men of the Trees.) $6 d$. Right and Might: an Argument for an International Police Force. By Alan Burnett Rae. (Series B, No. 7B). Pp. 18. (London: The New Commonwealth.) $3 d$.

The Strangeways Research Laboratory, Cambridge. Report for 1934. Pp. 26. (Cambridge : Strangeways Research Laboratory.) Department of Scientiflc and Industrial Research. Report of the Chemistry Research Board for the Period ended 31st December 1934; with Historical Introduction and Report by the Director of Chemical Research. Pp. V+94. (London: H.M. Stationery Office.) 18. 6d. net. Empire Cotton Growing Corporation. Report of the Administrative Council of the Corporation submitted to the Fourteenth Annual General Meeting on May 28th, 1935. Pp. ii +66 . (London: Empire Cotton Growing Corporation.

Cotton Growing Corporation.) on behalf of the Government of Palestine.) Pp. 106. (London: Crown Agents for the Colonies.) $78.6 d$.

Agents of the Astronomer Royal to the Board of Visitors of the Royal Observatory, Greenwich, read at the Annual Visitation of the Royal Observatory, 1935, June 1. Pp. 24. (Greenwich : Royal Observatory.)

The Institution of Gas Engineers. Communication No. 107: 72nd Annual Report and Accounts of the Council of the Institution of Gas Engineers to be presented at the 72 nd Annual General Meeting to be held at the Institution of Civil Engineers, Great George Street,

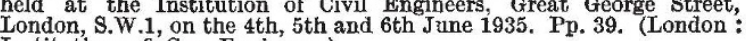
Institution of Gas Engineers.)

\section{OTHER COUNTRIES}

Indian Central Cotton Committee: Technological Laboratory. Technological Bulletin, Series B, No. 19: Effect of Storage prior to Ginning on the Spinning Quality of Cotton. By Dr. Nazir Ahmad. (Pp. 13). (Bombay : Indian Central Cotton Committee.) 8 annas. Canada : Department of Mines: Mines Branch. Investigations in July to December 1933. (No. 744.) Pp. iv +194. (Ottawa: King's Printer.)

Scent and the Weather. By Flight-Lieut. R. G. Veryard. (No. 1935/3.) Pp. iv $+33+5$ plates. (Chaman, Baluchistan: The Masters of Foxhounds Association of India.) 3 rupees.

Studies from the Connaught Laboratories, University of Toronto. Vol. 6: 1933-1934, Pp. vii 78 papers. (Toronto: University of Toronto Press.)

Survey of India. General Report, 1934, from 1st October 1933 to 30th September 1934 Pp. vi $+73+11$ plates. (Calcutta: Survey of 30th September 1934. Pp. vit

India Meteorological Department. Scientific Notes, Vol. 6 , No. 61: Evaporation in India calculated from other Meteorological 61: Evaporation in India calculated from other Meteorological (Dacthi: Manager of Publications.) 1.12 rupees ; 38.

(Delhi: Manager of Publications.) 1.12 rupees; 38. Thên Imperial Report of the Aeronautical Research Institute, Tokyo Imperial
University. No. 119: Buckling and Failure of 'Thin Rectangular Plates in Compression. By Mineo Yamamoto and Kazuo Kondo. Pp. 22. 25 sen. No. 120: Further Studies on the Effect of the Ground upon the Lift of a Monoplane Aerofoil. By Susumu Tomotika. Pp. 23-44. 25 sen. (Tôkyố: Kôgyô Tosho Kabushiki Kaisha.)

Ministry of the Interior, Egypt: Department of Public Health. The Research Institute and the Endemic Diseases Hospital : Third Annual Report 1933. Pp. xii $+108+14$ plates. (Cairo : Government Press.) Ministry of Public Works, Egypt: Physical Department. Helwan Observatory Bulletin No. 38: Sixth List of Nebulae photographed with the Reynolds Reflector. By M. R. Madwar. Pp. 15. (Cairo: Government Press.) 5 P.T.

Science Reports of the Tokyo Bunrika Daigaku, Section A. No. 40: On the Theory of Multivalent Functions. By Shigeo Ozaki. Pp. 167-188, (Tokyo: Maruzen Co., Ltd.) 35 sen.

The University of Colorado Studies. Vol. $22, \mathrm{Nos} .2$ and 3 : The Poetry of José Mármol. By Dr. Stuart Cuthbertson. (University of Colorado Bulletin, Vol. 35, No. 12.) Pp. iv +83-276. (Boulder, Colo.: University of Colorado.) 2 dollars.

Meddelanden från Statens Meteorologisk-Hydrografiska Anstalt. Band 6, No. 4: Höjdbestämningar vid Sveriges kuster medelst hydrografisk Nivellering. Av Folke Bergsten. Pp. 10. (Stockholm : Statens Meteorologisk-Hydrografiska Anstalt.) $1.50 \mathrm{kr}$.

Statens Meteorologisk-Hydrograflska Anstalt. Arsbok, 14, 1932. iii. Vattenstånden vid Rikets kuster. Pp. $25.2 .00 \mathrm{kr}$. Arsbok, 15,
1933. v. Hydrograflska mätningar i Sverige. Pp. $39.3 .00 \mathrm{kr}$. vi. Aerologiska iakttagelser i Sverige. Pp. 11. 2.50 kr. Årsbok, 16, A34. i. Månadsöversikt över väderlek och vattentillgång jämte 1934. i. Månadsöversikt över väderlek och vattentillgang jamte
anstaltens arsberăttelse. Pp. $89.2 .50 \mathrm{kr}$. (Stockholm: Statens Meteorologisk-Hydrografiska Anstalt.) 